\title{
A Study on Irrigation and Agricultural Productivity in Odisha
}

\author{
Urmi Pattanayak" and Minati Mallick
}

Department of Economics, North Orissa University, Baripada, Mayurbhanj, Odisha, India

*Corresponding author: urmi14989@gmail.com

\begin{abstract}
Irrigation is a critical component in the agricultural production as rainfall is inadequate, uncertain and uneven in an agrarian state like Odisha. The intensity of irrigation is an important determinant of the cropping pattern and agricultural productivity. The present paper studies the impact of irrigation on agricultural productivity in Odisha. The 30 districts of the state are grouped on the basis of their irrigation intensity and agricultural productivity. For the purpose Kendall's Ranking Coefficient method and Skewed distribution are used. It is found that the district of Puri tops the list with an irrigation intensity of 80.79 followed by Bhadrak district with 71.91. The Balasore district is at the third position (66.85) while the district of Bolangir has lowest intensity value i.e 20.64. Similarly, considering the agricultural productivity, it is observed that Kendrapada district is at the top with coefficient value of 25.14 followed by Boudh and Sambalpur with coefficient of (19.42) each. The relationship between irrigation intensity and agricultural productivity establishes that irrigation plays a vital role in enhancing the productivity. Sincere involvement of government, policy makers, planners, farmers and NGOs can achieve the goal of self sufficiency in agricultural production through promotion of irrigation.
\end{abstract}

Keywords: Irrigation, Agriculture, Intensity, Productivity

Water, the most precious natural resource which covers almost three-fourths of earth surface, has been instrumental in shaping the life of the people inhabiting on the earth since time immemorial. Early civilization developed and flourished on the banks of major rivers like Tigris and the Euphrates in Mesopotamia, the Nile in Egypt, the Huang-Ho in China and Indus River in India. For all types of agriculture such as geoponic, aeroponic and hydroponic, water is a basic component. Therefore, irrigation has acquired increasing importance in agriculture all over the world.

Irrigation is identified as a decisive factor in Indian agriculture due to high variability and inadequacy of rainfall. It is basically an agriculture operation and supplying the need of water for plants. According to the 2011 census of India, 61.8 percent of the working population are engaged in agricultural activities. The agricultural contribution to the GSDP is 16.3 percent in the fiscal year 2013-14 and it is estimated to be 15.4 percent in 2014-15 (give source).

Odisha is endowed with rich surface and ground water resources. The importance of agriculture in Odisha can hardly be undermined inspite of the fact that the sector contributes only a fifth to the Gross State Domestic Product. The agriculture sector provides employment to more than three fifths of total workforce of the state. The majority of the total population in rural Odisha has agriculture as the prime source of livelihood. Agriculture has been associated with production of essential food crops. The state has bagged the Krishi Karman Award for being the best performing state in food grain production among category-II in India for four times in five years (source). In 2014-15, Odisha produces 118 lakh metric tonne of food grains against 96 lakh metric tonne in 2013-14. It consumes 75 percent of the state water resources. About 58.78 percent of the net area sown is benefited by irrigation (source).

In this backdrop an attempt has been made in the present paper to study the impact of irrigation on agricultural productivity in Odisha state. It is organised in the following manner. The second section presents the Review of Literature. Data and 
Methodology are given in section -III. Results and discussion are presented in Section-IV followed by the concluding section.

\section{Review of Literature}

In this section a review of past research in the field has been compiled to enable better understanding of the problems concerned to the study.

Ghosh \& Kumar (2010) analysed the "Performance of Irrigation and Agricultural sector on Orissa: An analysis of Missing links" explained agricultural growth holds the key to the overall development of Orissa state by way of creating employment, generating income, providing raw materials to the industrial sector and ensuring self reliance in food production and food security. However, the agricultural growth is slow as compared to growth in irrigation sector. The gap between potential created and potential utilised is to be bridged to provide the benefits to farmers. The linkage between irrigation and agriculture functionaries needs to be strengthened to tap the potential and bring about improvement is farming, livelihood of farmers and state's economy.

Harish (2010) in his study "Irrigation projects in Chamarajanagar District: A Report" find the sustainability of the irrigation depends on the amount of rainfall and their use in the catchment area and the amount of fresh water released from the dams in Chamarajanagar district for agriculture. The operation of irrigation system is high degree between the district irrigation management and the user for maximizing benefit. The irrigated and non irrigational land users are commonly mediated at the district level for the existing crisis on water. These dams reduce the storage capacity and sustainability for the longer duration of water flow for irrigation by silt from the rivers. Therefore, irrigation to agriculture plays a major role in the Chamarajanagar district.

Kadigi et al. (2012) in their paper on "Irrigation and Water use Efficiency in Sub-Saharan Africa" identified the factors which can determine success or failure. The Sub-Saharan Africa countries suffer from a shortage of extension workers at about one per 200 farmers. As a result the minor irrigation scheme was failure due to a combination of factors including high investment cost, poor planning and lack of irrigation. Thus, small scale farmers faces many problems that is high costs of fertilizer, seeds and pesticides, poor marketing system.

Gitte (2013) in the article on "Development and Management of Water Resources in Maharashtra" examined that the irrigation sector in Maharashtra is the largest in the country. The irrigation policy should assign first priority to complete ongoing irrigation projects which are in advanced stage of development. The Government should earmarked sufficient funds for this sector in the state budget. It is also essential to manage and suggested strategies for improving the performance of irrigation sector and also to solve water related disputes in the state.

Pandey (2014) in his working paper on "Groundwater Irrigation in Punjab: Some Issues and Way Forward" focused the groundwater overexploitation is complex and very much influenced by numerous natural, economic and political factors at play and gradual shift in cropping pattern through innovative farming and irrigation methods or technology.

Shinde et al. (2015) in their research work on "Optimal Cropping Pattern for Sustainable Water use in Canal Command Area" estimated the cropping pattern formaximizing the net returns per unit of area per unit of available water resources. The study concluded that rabi paddy would not be found feasible in terms of water availability and benefits obtained. The vegetable and horticultural crop showed potential in the command area with the available water source to get maximum net returns. The maximum net returns can be obtained by adopting the horticultural plus vegetables plus pulses cropping pattern.

Reddy et al. (2015) had written an article on "Dynamics of Well Irrigation Systems and $\mathrm{Co}_{2}$ Emissions in Different Agro Ecosystems of South Central India" and suggested that $\mathrm{CO}_{2}$ in irrigation water use component was maximum in all the selected crops rice, sugarcane, maize, groundnut and vegetables under four different irrigation systems, viz. surface, rain-gun, sprinkler and drip irrigation from tube and dug wells. The agro ecosystems, it was found that the rain fed ecosystem produces higher $\mathrm{CO}_{2}$ due to increased well density and pumping. The modern irrigation system and alternate cropping system may be popularized among the farmers by providing incentives for both 
water credits and carbon credits as per reduced $\mathrm{CO}_{2^{\prime}}$ so that the environment as well as the available water resources are protected.

\section{Objectives}

The objectives of the present study are as follows:

1. To calculate the irrigation intensity in Odisha.

2. To examine the agricultural productivity in the study region.

3. To find out the impact of irrigation on agricultural production in Odisha state.

\section{Methodology}

\section{Study Area}

The study covers the state of Odisha which has a geographical area of 1,55,707 sq. kms. and is divided into ten agro climatic zones depending upon the soil types, topography, rainfall and cropping pattern. It is constituted by 30 districts. The total cultivated land of the State is 61.80 lakh ha out of which 29.14 lakh ha (47 percent) is high land, 17.55 lakh ha (28 per cent) medium land and 15.11 lakh ha ( 25 percent) low land and about 54 percent of cultivated land is irrigated. The climate of the state is tropical, characterised by high temperature, high humidity and medium to high rainfall, short \& mild winter. The normal rainfall is $1451.2 \mathrm{~mm}$. Most of the rainfall received in the state is concentrated over a period of 3 months of the monsoon season. The net area sown and gross cropped area during the year 2013-14 were 54.24 lakh ha and 90.54 lakh ha respectively. The cropping intensity is 167 percent. Rice is the major crop in Kharif season and pulses \& oilseeds in Rabi season. The gross irrigation potential created till 2013-14 from all sources is 50.05 lakh ha (33.53lakh ha during Kharif and 16.52 lakh ha during Rabi) and gross irrigated area during the year is 35.21 lakh ha (22.54 lakh ha during Kharif and 12.67 lakh ha during Rabi) which is 70.35 per cent of the irrigation potential created (give source).

\section{The Data}

The present study makes use of secondary data at district level drawn from Odisha Agricultural Statistics published by Department of Agriculture, Odisha, Odisha statistical abstract and Economic Survey of Odisha at one point time i.e. 2013-14.
District wise area under irrigation and agricultural productivity are used.

\section{Statistical Tools}

Following statistical tools are used for data analysis:

- Objective-1: Intensity of Irrigation- The intensity of irrigation is calculated by finding the proportion of net irrigated area to net sown area of the aerial unit. The intensity of irrigation is calculated as four categories on the basis of Skewed distribution such as, 1. High Intensity of Irrigation, it includes greater than mean value plus standard deviation. 2. Moderately High Intensity of Irrigation examine less than mean value plus standard deviation but greater than mean value. 3. greater than Mean value minus Standard deviation and less than mean score it include Moderately Low intensity of irrigation and lastly low intensity of irrigation means less than mean value minus standard deviation.

- Objective-2: Kendall's Ranking Coefficient method is used to rank the major crops like paddy, wheat, maize, black gram, green gram and sugarcane grown in the districts on the basis of their productivity. Then the arithmetic mean of these ranks is obtained which is called as Kendal's Ranking Co-efficient and the same is represented cartographically. Here, lower the coefficient value, higher is the productivity level of agriculture. Agricultural productivity is represented in same manner as Skewed Distribution of Intensity of Irrigation is classified.

- Objective-3: The statistical and cartographic techniques are used for representation of the relationship between irrigation intensity and agricultural productivity in the study region.

\section{RESULTS AND DISCUSSION}

\section{Intensity of Irrigation}

Irrigation is a critical component in the agricultural production as rainfall is inadequate, uncertain and uneven in an agrarian state like Odisha. The cropping pattern and the agricultural productivity in the state are greatly defined by irrigation. Thus the intensity of irrigation that shows the proportion 
of area under irrigation to net sown area is an important determinant of the cropping pattern and agricultural productivity. It is controlled by various factors such as source of irrigation, quantity and quality of water supply, intensity of network of water channels.

On the basis of the irrigation intensity all the 30 districts of the state are grouped under four categories i.e. high, moderately high, moderately low and low irrigation intensity and presented in Table $1 \& 2$. The result shown is district wise irrigation intensity in Fig. 1.

Table 1: Irrigation Intensity of Odisha 2013-14

\begin{tabular}{|c|c|c|c|}
\hline $\begin{array}{l}\text { Sl. } \\
\text { No }\end{array}$ & $\begin{array}{l}\text { Irrigation } \\
\text { Intensity }\end{array}$ & $\begin{array}{c}\text { No. of } \\
\text { Districts }\end{array}$ & Name of the Districts \\
\hline 01 & High & 8 & $\begin{array}{c}\text { Puri, Bhadrak, Kendrapada, } \\
\text { Jagatsingpur, Balasore, } \\
\text { Subarnapur, Cuttack, } \\
\text { Dhenkanal. }\end{array}$ \\
\hline 02 & $\begin{array}{c}\text { Moderately } \\
\text { High }\end{array}$ & 5 & $\begin{array}{c}\text { Khordha, Jajpur, Bargarh, } \\
\text { Malkangiri, Ganjam. }\end{array}$ \\
\hline 03 & $\begin{array}{l}\text { Moderately } \\
\text { Low }\end{array}$ & 15 & $\begin{array}{l}\text { Deogarh, Boudh, Nayagarh, } \\
\text { Gajapati, Kalahandi, } \\
\text { Mayurbhanj, Sambalpur, } \\
\text { Keonjhar, Koraput, Angul, } \\
\text { Sundargarh, Rayagada, } \\
\text { Kandhamal, Nuapada, } \\
\text { Jharsuguda. }\end{array}$ \\
\hline 04 & Low & 2 & Nabarangpur, Bolangir. \\
\hline
\end{tabular}

Source: Computed by Authors

Table 2: District Wise Irrigation Intensity of Odisha 2013-14

\begin{tabular}{ccc}
\hline S1. No. & $\begin{array}{c}\text { Name of the } \\
\text { Districts }\end{array}$ & Irrigation Intensity (\%) \\
\hline 1 & Angul & 28.52 \\
2 & Balasore & 66.85 \\
3 & Bargarh & 46.18 \\
4 & Bhadrak & 71.91 \\
5 & Bolangir & 20.64 \\
6 & Boudh & 37.15 \\
7 & Cuttack & 64.8 \\
8 & Deogarh & 37.77 \\
9 & Dhenkanal & 58.8 \\
10 & Gajapati & 36.53 \\
11 & Ganjam & 41.98 \\
12 & Jagatsingpur & 66.95 \\
13 & Jajpur & 50.73 \\
14 & Jharsuguda & 25.16
\end{tabular}

Source: Computed by Authors

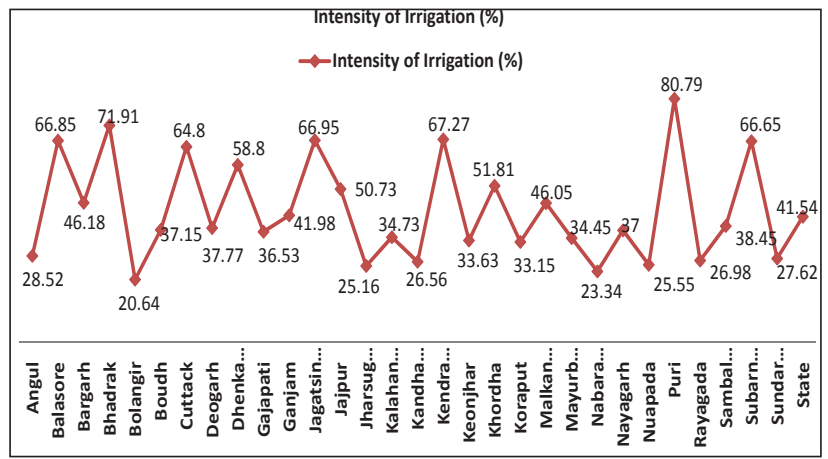

Fig. 1: District wise Irrigation Intensity of Odisha

\section{High Irrigation Intensity}

A cursory glance at the table reveals that 8 districts of the state have high irrigation intensity out of which six are coastal districts so lie in plain area. Besides irrigation project the districts also exploit their rich ground water resource for agricultural purposes. In this category Puri enjoys highest irrigation intensity of 80.79 percent followed by Bhadrak (71.91\%) and Kendrapara $(67.27 \%)$. Dhenkanal is in the bottom of the list with an irrigation intensity of 58.80 per cent.

\section{Moderately High Irrigation Intensity}

Out of thirty districts of the state five districts namely Khordha, Jajpur, Baragarh, Malkangiri and Ganjam enjoy moderately high irrigation intensity with 51.8, 50.73, 46.18, 46.05 and 41.98 per cent respectively. 


\section{Moderately Low Irrigation Intensity}

15 districts of the state were having low irrigation intensity from among which Deogarh tops the list with 37.77 per cent of its net sown area being irrigated. Jharsuguda is at the bottom with an intensity of only 25.16 per cent.

\section{Low Irrigation Intensity}

Only two districts namely Nabarangpur and Bolangir were there in this category with irrigation intensity as low as 23.34 and 20.64 per cent respectively.

\section{Agricultural Productivity}

The agricultural productivity that is the yield per hectare reflects regions efficiency in agriculture. Using Kendal's ranking coefficient method (1968) an attempt has been made here to find out the agricultural productivity in the 30 districts of state of Odisha and categorise them into areas of high productivity, moderately high productivity, moderately low productivity and low productivity which are presented in Table $3 \& 4$. For the purpose seven major crops grown in all the districts were considered which are ranked in order of their productivity. Then the arithmetic mean of the ranks was calculated which was called Kendal's ranking coefficient. Lower the coefficient value higher is the productivity and vice-versa.

\section{High Agricultural Productivity}

Out of 30 districts of the state three districts namely Jajpur, Deogarh and Malkangiri were included in the area of high agricultural productivity. The rivers in this area provide water for irrigation in Rabi season. The river basins have fertile soils and many farmers in this area are adopting new inputs in agriculture by using fertilizers, machinery, improved seeds etc.

\section{Moderately High Agricultural Productivity}

This category of productivity covers 13 districts. The coefficient value in this area ranges from greater than 11.82 and less than 15.15. Bolangir and Cuttack are the highest rank for pulses cultivation. Other districts like Bolangir, Gajapati, Dhenkanal have fertile soil but paucity of water for irrigation and high variability of rainfall have resulted into moderate high agricultural productivity.

\section{Moderately Low Agricultural Productivity}

10 districts includes in this category. The productivity range is greater than 15.15 and less than 18.48 the coefficient value. Rayagada is the highest area of agricultural productivity followed by Balasore and Bhadrak whereas Nuapada and Kandhamal are the lowest areas of productivity in this category.

\section{Low Agricultural Productivity}

The low productivity areas cover four districts where the coefficient value is above 18.48. The high variability of rainfall and low intensity of irrigation have led to low agricultural productivity in dry areas of the district.

Table 3: Agricultural Productivity of Odisha 2013-14

\begin{tabular}{|c|c|c|c|}
\hline $\begin{array}{l}\text { S1. } \\
\text { No }\end{array}$ & $\begin{array}{l}\text { Agricultural } \\
\text { Productivity }\end{array}$ & $\begin{array}{c}\text { No. of } \\
\text { Districts }\end{array}$ & Name of the Districts \\
\hline 01 & High & 3 & $\begin{array}{l}\text { Jajpur, Deogarh, } \\
\text { Malkangiri }\end{array}$ \\
\hline 02 & $\begin{array}{l}\text { Moderately } \\
\text { High }\end{array}$ & 13 & $\begin{array}{c}\text { Angul, Cuttack, Bolangir, } \\
\text { Gajapati, Dhenkanal, } \\
\text { Nabarangpur, Khordha, } \\
\text { Bargarh, Keonjhar, } \\
\text { Jharsuguda, Subarnapur, } \\
\text { Puri, Koraput. }\end{array}$ \\
\hline 03 & $\begin{array}{l}\text { Moderately } \\
\text { Low }\end{array}$ & 10 & $\begin{array}{l}\text { Rayagada, Balasore, } \\
\text { Bhadrak, Mayurbhanj, } \\
\text { Kalahandi, Ganjam, } \\
\text { Sundargarh, Nayagarh, } \\
\text { Nuapada, Kandhamal. }\end{array}$ \\
\hline 04 & Low & 4 & $\begin{array}{l}\text { Jagatsingpur, Sambalpur, } \\
\text { Boudh, Kendrapada. }\end{array}$ \\
\hline
\end{tabular}

Source: Computed by Authors.

Table 4: Ranking Wise Agricultural Productivity of Odisha 2013-14

\begin{tabular}{cccc}
\hline Sl. No. & $\begin{array}{c}\text { Name of the } \\
\text { Districts }\end{array}$ & $\begin{array}{c}\text { Kendal's Ranking } \\
\text { Coefficient }\end{array}$ & Ranks \\
\hline 1 & Angul & 11.85 & 18 \\
2 & Balasore & 15.85 & 10 \\
3 & Bargarh & 14 & 15 \\
4 & Bhadrak & 16 & 9 \\
5 & Bolangir & 12 & 17 \\
6 & Boudh & 19.42 & 2 \\
7 & Cuttack & 12 & 17 \\
8 & Deogarh & 11.28 & 20 \\
9 & Dhenkanal & 12.71 & 17
\end{tabular}




\begin{tabular}{lccc}
10 & Gajapati & 12.42 & 17 \\
11 & Ganjam & 16.57 & 7 \\
12 & Jagatsingpur & 18.71 & 3 \\
13 & Jajpur & 7 & 21 \\
14 & Jharsuguda & 14.57 & 13 \\
15 & Kalahandi & 16.42 & 8 \\
16 & Kandhamal & 18.42 & 4 \\
17 & Kendrapada & 25.14 & 1 \\
18 & Keonjhar & 14.28 & 14 \\
19 & Khordha & 14 & 15 \\
20 & Koraput & 15 & 12 \\
21 & Malkangiri & 11.57 & 19 \\
22 & Mayurbhanj & 16.42 & 8 \\
23 & Nabarangpur & 13.28 & 16 \\
24 & Nayagarh & 16.71 & 6 \\
25 & Nuapada & 17.71 & 5 \\
26 & Puri & 15 & 12 \\
27 & Rayagada & 15.20 & 11 \\
28 & Sambalpur & 19.42 & 2 \\
29 & Subarnapur & 16.71 & 6 \\
30 & Sundargarh & 15 & 12 \\
\hline
\end{tabular}

Source: Computed by Authors.

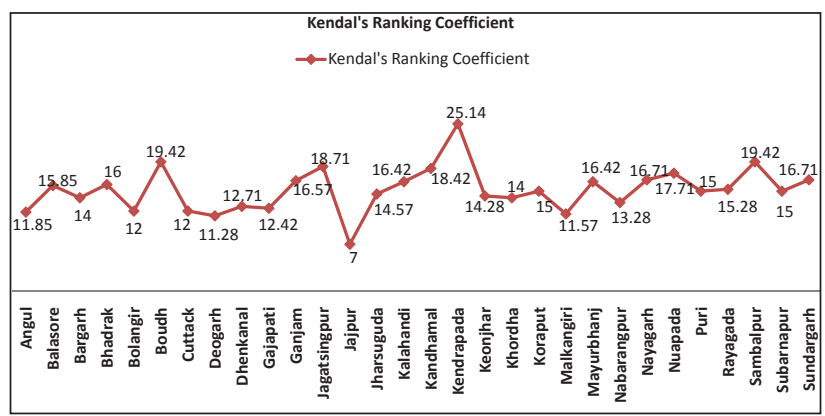

Fig. 2: Ranking Wise Agricultural Productivity of Odisha

\section{Relationship between Irrigation Intensity and Agricultural Productivity in Odisha}

Table3 represents the relationship between irrigation intensity and agricultural productivity in Odisha. Irrigation is backbone of agriculture in drought prone area. The choice of cropping pattern, variety crops and methods of cultivation also depends on irrigation. There are close relationship between moderately high intensity of irrigation and moderately high agricultural productivity same as also moderately low irrigation of intensity and moderately low agricultural productivity in study region. In the state of Odisha the positive co-relation largely (29.99\% to district) observed in nine districts of the state. These districts are Bargarh, Khordha,
Rayagada, Mayurbhanj, Kalahandi, Sundargarh, Nayagarh, Nuapada and Kandhamal. It clearly explains that the irrigation affects agricultural productivity in the study region. If irrigation area is increased, the agricultural productivity is also increased.

Four districts namely Cuttack, Dhenkanal, Puri and Subarnapur include in high intensity of irrigation and moderately high agricultural productivity and are called Perfect positive co-relation (13.33\%). Because in these districts irrigation facilities has been developed. These areas captures by river which had tremendously provided water for irrigation therefore agricultural productivity is high and also they produced different types of crops for different seasons. In these areas pluses and cereals are the main crops.

Balasore and Bhadrak include the high intensity of irrigation but moderately low agricultural productivity. There is a negative co-relation because of low agricultural productivity due to traditional way of farming and lacking of input efficiency like fertilizers, seeds etc.

The perfect negative co-relation was observed in two districts namely, Jagatsingpur and Kendrapada. There was high intensity of irrigation but low agricultural productivity because in these districts agricultural productivity influence by irrigation as well as socio-economic and cultural factors in irrigation projects is high irrigation due to some river flows and canals provide enormous water of irrigation. But low productivity due to monoculture crop and land holding size is large.

In Jajpur and Malkangiri districts beneficial positively co-relation and it is observed in these district moderately high irrigation intensity and high agricultural productivity with 6.66 percent of state. Whereas Ganjam includes moderately high intensity of irrigation but moderately low agricultural productivity due to low fertility and labour problems.

The negative co-relation was also observed in Deogarh District. In this district agricultural productivity was high but moderately low irrigation intensity due to low rainfall region and no canal or other irrigation sources developed.

Five districts include Angul, Gajapati, Keonjhar, Koraput and Jharsuguda observed moderately 
low intensity of irrigation but moderately high agricultural productivity where it is a negative corelation due to lack of water storage.

Perfect negative co-relation observed in two districts Boudh and Sambalpur of the state. Moderately low intensity of irrigation and low agricultural productivity was observed which means that in these two region irrigation sources are developed but is having negative influence due to insufficiency of water and lack of labour problem, and not proper management of well and canals.

In Bolangir and Nabarangpur districts beneficial negative co-relation observed means in these districts irrigation intensity is low but agricultural productivity is moderately high. These two districts were located in low rainfall and irrigation sources were not developed. But the farmers of the districts largely used micro irrigation system, low water crops for cultivation (fruits crops) and favourable soil for fruit cultivation. Therefore, the moderately high agricultural productivity observed.

Table 3: Relationship between Irrigation Intensity and Agricultural Productivity in Odisha

\begin{tabular}{|c|c|c|c|c|}
\hline $\begin{array}{l}\text { Sl. } \\
\text { No. }\end{array}$ & $\begin{array}{c}\text { Level of } \\
\text { Irrigation } \\
\text { and } \\
\text { Productivity }\end{array}$ & $\begin{array}{c}\text { No. of } \\
\text { Districts }\end{array}$ & $\begin{array}{l}\% \text { to } \\
\text { Total }\end{array}$ & District Name \\
\hline 1 & HI, HP & Nil & - & - \\
\hline 2 & HI, MHP & 4 & 13.33 & $\begin{array}{c}\text { Cuttack, Dhenkanal, } \\
\text { Puri, Subarnapur }\end{array}$ \\
\hline 3 & HI, MLP & 2 & 6.66 & Balasore, Bhadrak \\
\hline 4 & HI, LP & 2 & 6.66 & $\begin{array}{l}\text { Jagatsingpur, } \\
\text { Kendrapada }\end{array}$ \\
\hline 5 & MHI, HP & 2 & 6.66 & Jajpur, Malkangiri \\
\hline 6 & MHI, MHP & 2 & 6.66 & Bargarh, Khordha \\
\hline 7 & MHI, MLP & 1 & 3.33 & Ganjam \\
\hline 8 & MHI, LP & Nil & - & - \\
\hline 9 & MLI, HP & 1 & 3.33 & Deogarh \\
\hline 10 & MLI, MHP & 5 & 16.66 & $\begin{array}{c}\text { Angul, Gajapati, } \\
\text { Keonjhar, Koraput } \\
\text { Jharsuguda }\end{array}$ \\
\hline 11 & MLI, MLP & 7 & 23.33 & $\begin{array}{c}\text { Rayagada, } \\
\text { Mayurbhanj, } \\
\text { Kalahandi, } \\
\text { Sundargarh, } \\
\text { Nayagarh, Nuapada, } \\
\text { Kandhamal. }\end{array}$ \\
\hline 12 & MLI, LP & 2 & 6.66 & Boudh, Sambalpur \\
\hline 13 & LI, HP & Nil & - & - \\
\hline
\end{tabular}

\begin{tabular}{ccccc}
14 & LI, MHP & 2 & 6.66 & $\begin{array}{c}\text { Bolangir, } \\
\text { Nabarangpur }\end{array}$ \\
15 & LI, MLP & Nil & - & - \\
16 & LI, LP & Nil & - & - \\
\hline
\end{tabular}

Source: Computed by Authors.

\section{CONCLUSION}

It is thus observed that agricultural productivity largely influenced by irrigation. For achieving higher productivity in agriculture promotion of irrigation facilities is highly imperative. More dams, watersheds need constructed to preserve water for irrigation purposes. Rain water harvesting is an amicable way in drought prone and desert like areas. The farmers need to be trained in the technique of rain water harvesting and the methods of increasing water use efficiency. Drip irrigation, sprinkler irrigation methods needs to be promoted. Electronic and print media can go a long way in awareness creation regarding this. Moreover, government should take initiatives to allocate more funds for the irrigation. The help of NGOs can be taken resort to ensure efficient water management involving the farmers.

Agricultural sector is vital to the economy. Higher production is necessary to feed an expanding population. The sincere involvement of government, policy makers, planners, farmers and NGOs can achieve the goal of self-sufficiency in agricultural production through promotion of irrigation.

\section{REFERENCES}

Ghosh, S. and Kumar, A. 2010. Performance of Irrigation and Agricultural Sector in Orissa: An Analysis of Missing Links. Indian Res. Jo. Exten. Edu., 10(2): 48-54.

Gitte, M.R. 2013. Development and Management of Water Resources in Maharashtra. Int.J.Human.Soc.Sci.Inven., 2(4).

Harish, M. 2010. Study on Irrigation Projects in Chamarajanagar District: A Report. J. Chem. Rasayan, 3(4).

Kadigi, R.M. J. et al. 2012. Irrigation and Water use Efficiency in Sub-Saharan Africa. GDN Agriculture Policy Series, Working Paper, 04: 1-7.

Pandey, R. 2014. Ground Water Irrigation in Punjab: Some Issues and Way Forward. Working Paper 140: 1-21. www. nipfp.org.in.

Reddy, K.S. et al. 2015. Dynamics of Well Irrigation Systems and $\mathrm{CO}_{2}$ Emissions in Different Agro ecosystems of South Central India. Cur. Sci., 108(11): 2063-2070.

Shinde, S.E. et al. 2015. Optimal Cropping Pattern for Sustainable Water Use in Canal Command Area. Res. J. Rec. Sci., 3(4). 
